\title{
DENTAL DISEASES OF DOGS: A RETROSPECTIVE STUDY OF RADIOLOGICAL DATA
}

\author{
V. BUTKOVIĆ ${ }^{1}$, M. S̆IMPRAGA ${ }^{2}$, M. ŠEHIĆ ${ }^{1}$, D. STANIN ${ }^{1}$, V. SUŠIĆ ${ }^{3}$, D. CAPAK ${ }^{4}$, J. KOS $^{4}$ \\ ${ }^{1}$ Department of Roentgenology, Ultrasonic Diagnostics and Physical Therapy, ${ }^{2}$ Department of Physiology \\ and Radiobiology, ${ }^{3}$ Department for animal husbrandy, ${ }^{4}$ Surgery, Orthopaedics \& Ophtalmology Clinic,
} Veterinary Faculty University of Zagreb, Croatia

\section{Received June 14, 1999}

Accepted May 28, 2001

\section{Abstract}

Butković V., M. Šimpraga, M. Šehić, D. Stanin, V. Sušić, D. Capak, J. Kos: Dental Diseases of Dogs: a Retrospective Study of Radiological Data. Acta Vet. Brno 2001, 70: 203-208.

The purpose of the present study was to assess the number of pathological dental changes and anomalies in dogs. The incidence of dental diseases was investigated in radiologically examined 139 males dogs and 120 females dogs, aged seven months to 15 years. There were 235 purebred dogs and 24 mongrels. The oral cavity was clinically examined and radiographed. The incidence and extent of oligodontia, periodontitis, dental fractures and rotations, persisting deciduous teeth and supernumerary teeth were recorded. It has also been established that $30 \%$ of dogs presented more than one anomaly. The incidence of oligodontia equalled to $45.17 \%$, peridontitis $44.40 \%$, fracture $19.30 \%$, tooth rotation $11.59 \%$, persisting deciduous teeth $5.40 \%$ and supernumerary teeth $3.86 \%$. Our results have shown that incidence of dental changes and anomalies differed significantly between dogs of different age groups. The highest incidence of oligodontia, tooth rotation, retained deciduous teeth and supernumerary teeth was observed in the youngest age group $(p<0.001)$, dental fracture in the mid-age group $(p<0.001)$ and peridontitis in the mid-age and oldest age group $(p<0.001)$. Considering the hereditary nature of the anomalies such as congenital oligodontia, tooth rotation and retained deciduous teeth, dog breeders should provide for a timely X-ray examination and, in case of these anomalies, exclude the affected dogs from further breeding.

Oligodontia, periodontitis, tooth fracture, tooth rotation, retained deciduous teeth, supernumerary teeth

The results of analysis of pathological findings in dogs of all ages have shown that diseases and anomalies of the oral cavity are the most frequent ones. Among these changes, clinically diagnosed gingivitis is the most common (Harvey 1996; Smith 1985). According to a research carried out by Harvey et al. (1983), the most frequent radiologically diagnosed change was periodontitis, which was found in $95 \%$ of dogs over 2 years of age.

The number of radiologically observed dental changes is increasing every year. There are different reasons for their occurrence. For example, greater care for animals, an ever increasing number of purebred dogs and more stringent cynological rules are only some of the factors contributing to more frequent dental examinations.

The purpose of the present study is to assess the number of pathological dental changes and anomalies in dogs, which can be diagnosed radiologically, together with the incidence thereof, by age categories.

\section{Materials and Methods}

The study was carried out on patients at the Department of Roentgenology, Ultrasonic Diagnostic and Physical Therapy, Faculty of Veterinary Medicine, University of Zagreb. During a four-year period, 9016 dogs were examined radiologically, 259 of them were sent by veterinarians and cynological judges for an X-ray examination due to various dental anomalies. Of this number, 235 dogs belonged to 23 breeds and 24 were mongrels. Only

Address for correspondence:

Dr. sc. Vladimir Butković

Department of Roentgenology, Ultrasonic Diagnostic And Physical Therapy

Veterinary Faculty University of Zagreb
Phone: +385 12390401

Fax: +385 12441390

http://www.vfu.cz/acta-vet/actavet.htm 
6 breeds were represented by ten or more dogs (Toy Poodle, Chihuahua, Poodle, German Shepherd, German Hunting Terrier, Boxer). There were 139 males and 120 females. The observed animals were subdivided into three age groups: from 7 months to 2 years; from terminated 2 yr to 8 years, and from terminated 8 years to 15 years (Table 1$)$.

Table 1

Age and sex distribution of the 259 dogs

\begin{tabular}{|c|c|c|c|}
\hline Age & No. of males & No. of females & Total \\
\hline $7 \mathrm{mo}-2 \mathrm{yr}$ & 64 & 53 & 117 \\
\hline $2-8 \mathrm{yr}$ & 59 & 55 & 28 \\
\hline $8-15 \mathrm{yr}$ & 16 & 12 & 259 \\
\hline Total & 139 & 120 & 14 \\
\hline
\end{tabular}

Radiological examination was carried out using a Müller - DA 1001, $150 \mathrm{kV}$ unit, at a distance of A - Fi $100 \mathrm{~cm}$. In the radiologic examination of teeth, extraoral and intraoral methods of X-ray monitoring were used. While taking a radiograph of the upper and lower molars and premolars, the dog was in lateral recumbency, with a casette placed under the examined area. We obtained good quality isometrical pictures using an angle of $40^{\circ}-50^{\circ}$ within the monitored area. This was achieved by using the sticks made at these angles. They were put under an area that had to be above the surface (upper or lower teeth). The mouth was opened by means of rubber mouth retractors or thin textile strips (Zontine 1975). The X-ray pictures were taken at 50-55 kV and 13-16 mA.

When taking the pictures of incisors, the dog was in ventral recumbency. The film was put into the mouth which was thereafter kept closed. The central X-ray was directed onto the central axis of the incisors at an angle of $20^{\circ}-30^{\circ}$. While taking the pictures of the lower incisors, the dog was in dorsal recumbency. The pictures were taken at $45-50 \mathrm{kV}$ and 13-16 mA. All radiographs were taken with high resolution screen cassettes and Kodak films 13 x 18 and 18 x $24 \mathrm{~cm}$.

For statistical evaluation of results Chi-square test $\left(\chi^{2}\right)(\mathrm{SAS}, 1989-1996)$ was used.

\section{Results}

Over a 4-year period, 9016 radiographs were analysed and in 259 animals (2.8\%) of all age groups (Table 1), 336 dental diseases and anomalies were found. The findings were classified in 6 categories: oligodontia, periodontitis, dental fracture, dental rotation, persisting deciduous teeth and supernumerary teeth (Table 2). In some dogs, more than one pathological change was found and that is why we have recorded a total of 336 changes, i.e. $29.72 \%$ of dogs presented more than one anomaly (Table 3).

Table 2

Number and incidence (\%) in different age groups of dogs with various dental diseases in all cases

\begin{tabular}{|c|c|c|c|c|c|c|c|c|c|c|}
\hline \multirow{3}{*}{$\begin{array}{l}\text { Diagnosis } \\
\text { Oligodontia }\end{array}$} & \multicolumn{6}{|c|}{ Age } & \multicolumn{2}{|c|}{ Total } & \multirow{2}{*}{\multicolumn{2}{|c|}{ Chi - Square }} \\
\hline & $\mathrm{N}^{0}$ & $7 \mathrm{mo}-2 \mathrm{yr}$ & $\mathrm{N}^{0}$ & $2-8 \mathrm{yr}$ & $\mathrm{N}^{0}$ & $8-15 \mathrm{yr}$ & $\mathrm{N}^{0}$ & $\%$ & & \\
\hline & 80 & 68.37 & 27 & 23.07 & 10 & 8.55 & 117 & 100.0 & 66.7 & $p<0.001$ \\
\hline Periodontitis & 0 & 0.00 & 87 & 75.62 & 28 & 24.35 & 115 & 100.0 & 103.8 & $p<0.001$ \\
\hline Fracture & 20 & 40.00 & 28 & 56.00 & 2 & 4.00 & 50 & 100.0 & 20.9 & $p<0.001$ \\
\hline Tooth rotation & 29 & 96.66 & 1 & 3.33 & 0 & 0,00 & 30 & 100.0 & 54.2 & $p<0.001$ \\
\hline $\begin{array}{c}\text { Retained } \\
\text { deciduous teeth }\end{array}$ & 14 & 100.00 & 0 & 0.00 & 0 & 0.00 & 14 & 100.0 & 26.2 & $p<0.001$ \\
\hline $\begin{array}{c}\text { Supernumerary } \\
\text { teeth }\end{array}$ & 9 & 90.00 & 1 & 10.00 & 0 & 0.00 & 10 & 100.0 & 16.3 & $p<0.001$ \\
\hline Total & 152 & 45.24 & 144 & 42.86 & 40 & 11.90 & 336 & 100.0 & & \\
\hline
\end{tabular}

Oligodontia was the most frequent change of all. The incidence of oligodontia was significantly different $(p<0.001)$ between dogs of different age groups. The highest incidence of oligodontia was established in young dogs $-68.37 \%$ (Table 3 ). Among these 
Table 3

Incidence (\%) of various dental disease in the different age groups of dogs and total incidence (\%) of various dental disease of all cases

\begin{tabular}{|c|c|c|c|c|}
\hline \multirow{2}{*}{ Diagnosis } & \multicolumn{3}{|c|}{ Age } & Total \\
\cline { 2 - 5 } & $7 \mathrm{mo}-2 \mathrm{yr}$ & $2-8 \mathrm{yr}$ & $8-15 \mathrm{yr}$ & $\%$ \\
\hline Oligodontia & 68.37 & 23.68 & 35.71 & 45.17 \\
\hline Periodontitis & 0.00 & 76.31 & 100.00 & 44.40 \\
\hline Fracture & 17.09 & 24.56 & 7.14 & 19.30 \\
\hline Tooth rotation & 24.78 & 0.88 & 0.00 & 11.59 \\
\hline Retained deciduous teeth & 11.96 & 0.00 & 0.00 & 5.40 \\
\hline Supernumerary teeth & 7.69 & 0.88 & 0.00 & 3.86 \\
\hline & & & & 129.72 \\
\hline Chi-Square & $162.7 p<0.001$ & $234.5 p<0.001$ & $88.9 p<0.001$ & \multicolumn{1}{c}{} \\
\cline { 1 - 4 } & &
\end{tabular}

117 dogs, 68 (58\%) presented congenital oligodontia and 49 presented acquired oligodontia. Of the total of 68 cases of congenital oligodontia, 44 cases $(64.70 \%)$ congenital oligodontia involved the lower jaw and 24 cases inolved the upper jaw. In these 44 cases of congenital oligodontia involving the lower jaw, the most frequent changes were observed on the first and the second premolars, namely, in 24 cases $(54,54 \%)$. In the upper jaw, congenital oligodontia was found in 24 cases $(35.29 \%)$, usually on the first premolar (in 8 cases, i.e. $33.33 \%$ ) (Fig. 1).

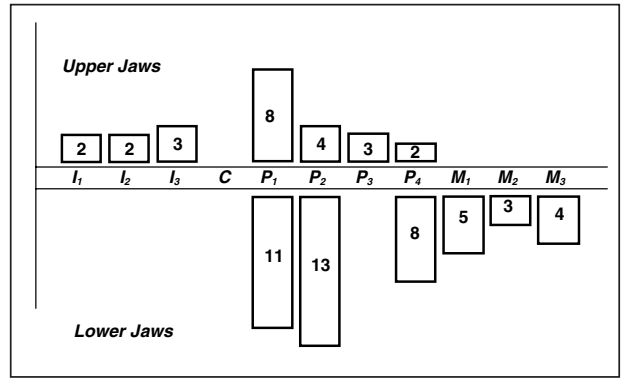

Fig. 1. Frequency of congenital oligodontia

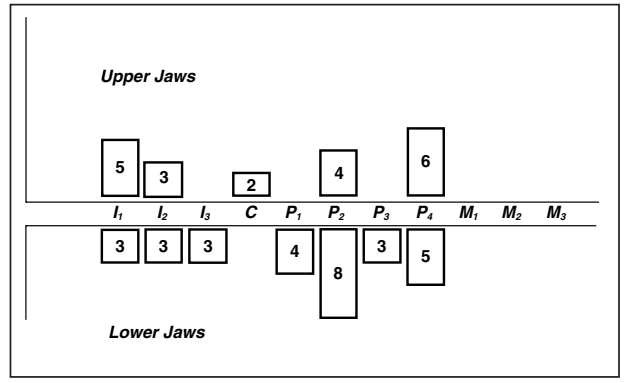

Fig. 2. Incidence of acquired oligodontia

Acquired oligodontia also more frequently involved the lower jaw: 29 cases (59.18\%), usually on the second and fourth premolars (Fig. 2). On the upper jaw, it was found in 20

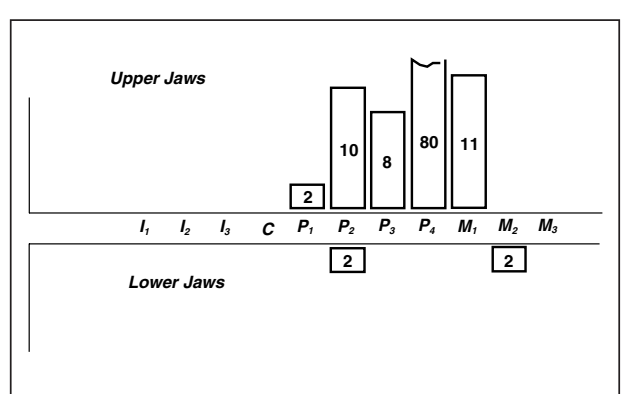

Fig. 3. Incidence of periodontitis on certain teeth cases $(40.82 \%)$, usually on the first incisor and the fourth premolar. In German Hunting Terrier (Jagdterrier) with dental diseases, oligodontia was found in $51 \%$ of the examined animals (Table 4).

Periodontitis was found in 115 out of 259 examined dogs (Table 2), which is equal to $44 \%$ (Table 3). The incidence of periodontitis was also statistically significant different $(p<0.001)$ between dogs of different age groups. Periodontitis most frequently affected the middle age dogs 
Table 4

Incidence $(\%)$ of various dental disease in various groups and breeds of dogs

\begin{tabular}{|c|c|c|c|c|c|c|c|}
\hline Group & Breed & Oligodontia & Periodontitis & Fracture & $\begin{array}{c}\text { Tooth } \\
\text { rotation }\end{array}$ & $\begin{array}{c}\text { Retained } \\
\text { deciduous } \\
\text { teeth }\end{array}$ & $\begin{array}{c}\text { Supernumerary } \\
\text { teeth }\end{array}$ \\
\hline \multirow{3}{*}{ Small } & Toy poodle & 2.0 & 10.0 & 0.0 & 0.0 & 74.4 & 2.0 \\
\hline & Chihuahua & 0.5 & 2.0 & 0.0 & 0.0 & 11.2 & 3.0 \\
\hline & Other & 1.0 & 8.0 & 7.0 & 1.5 & 10.0 & 18.0 \\
\hline \multirow[t]{3}{*}{ Medium } & $\begin{array}{l}\text { German } \\
\text { hunting terrier }\end{array}$ & 51.0 & 8.0 & 29.0 & 5.5 & 0.0 & 7.0 \\
\hline & Poodle & 7.0 & 20.0 & 0.0 & 5.0 & 0.0 & 5.0 \\
\hline & Other & 1.5 & 11.5 & 12.0 & 17.0 & 2.0 & 26.0 \\
\hline \multirow[t]{3}{*}{ Large } & $\begin{array}{l}\text { German } \\
\text { shepherd }\end{array}$ & 23.0 & 11.5 & 21.0 & 15.0 & 0.0 & 5.0 \\
\hline & Boxer & 10.0 & 9.0 & 16.0 & 11.0 & 0.0 & $4 . .0$ \\
\hline & Other & 4.0 & 5.8 & 15.0 & 45.0 & 2.4 & 24.0 \\
\hline \multirow[t]{2}{*}{ Mongrels } & & 0.0 & 14.0 & 0.0 & 0.0 & 0.0 & 6.0 \\
\hline & & 100.0 & 100.0 & 100.0 & 100.0 & 100.0 & 100.0 \\
\hline
\end{tabular}

(75.62\%) (Table 2) and usually involved the upper jaw (111 cases, i.e. 96.52\%), mostly the fourth premolar (80 cases, i.e. $72.07 \%$ ) and only in 4 cases $(3.47 \%)$ it involved the lower jaw (Fig. 3). Periodontitis was diagnosed in $20.0 \%$ of small breeds, in $39.5 \%$ of medium-size breeds, in $26.5 \%$ of large breeds and in $14.0 \%$ of mongrels (Table 4 ).

Dental fracture was diagnosed only in $19.3 \%$ of cases (Table 3 ). As with previous diseases, incidence of dental fracture was also significantly different $(p<0.001)$ between different age groups. Dental fracture was most frequently found in middle-age dogs (Table 2). German Hunting Terrier, Boxer and German Shepherd were the most frequent patients. In these $19.3 \%$ of the above-mentioned cases, the most frequently affected teeth were the incisors and the first premolar $(71.3 \%)$.

Dental rotation was found in $11.59 \%$ of all cases (Table 3$)$. Also, in these disease was noticed significant differences $(p<0.001)$ between different age groups. It was most frequently found in large breeds (Table 4 ) and in the youngest age group (Table 2). Dental rotation was frequently found in the lower jaw. The first premolar was rotated with rostrally directed crown in almost $95.0 \%$ of cases. Thus rotated teeth very often did not pierce through the alveolar bone and remained impacted. Therefore, rotation is often closely associated with impaction.

Persisting deciduous teeth were found in $5.4 \%$ of cases (Table 3 ). The differences in the incidences of these anomalies were significant among the age groups $(p<0.001)$. Small breeds accounted for $95.6 \%$ (Table 4), Toy Poodle in particular. This condition was found only in dogs of the age group from 7 months to 2 years (Table 2). In $91.0 \%$ of cases, the persistence involved the upper canines.

Of all established categories of dental changes and anomalies, supernumerary teeth were the least frequent one, accounting for only $3,86 \%$ (Table 3 ). In $85 \%$ of cases, it involved the first and second premolars. These changes equally affected the upper and the lower jaws. In $8 \%$ of cases the teeth were found outside of the central arch. The differences between each of three groups by age, were significant $(p<0.001)$ for in these anomalies. The highest incidence of supernumerary teeth was noted in the youngest age group - about $90 \%$ (Table 3 ) and affected equally all examined breeds (Table 4). 


\section{Discussion}

Our research has shown that dental diseases were found in $2.8 \%$ of the total number of radiologically examined dogs. It has been established that $30 \%$ of dogs presented more than one anomaly. Following a research carried out on 39500 dogs, Harvey (1996) established that oral diseases are the most frequent problem in dogs of all age groups. His study included the changes that could not be diagnosed radiologically, but they still formed the main pathological changes in the oral cavity. This is why our results differ from those of Harvey: we included only the changes on teeth and jaws which can be diagnosed radiologically.

Our research has shown that oligodontia could be either congenital or acquired, a fact that is in line with the reports found in the literature. The breed, oral structure and genetic features are mentioned as the factors contributing to the occurrence of congenital oligodontia (Bodingbauer and Hager 1959ab; Booessneck 1995abc; Schulze 1970). Acquired oligodontia is a result of general infections and parasitical diseases during dentition as well as of dental diseases and the conditions of the adjoining area including periodontitis, trauma or dental extraction, or dental loss at an advanced age (Bodingbauer 1960).

According to the case history data, trauma was the most frequent cause of dental loss. German Hunting Terrier accounted for $51 \%$ of all acquired oligodontia cases (resulting from fights) (Table 4). The incidence of oligodontia differed significantly $(p<0.001)$ between dogs of different age groups. Since oligodontia is so important from the cynological point of view, it is quite clear why it is most frequently found in young dogs (68.37\%) (Table 2). Logically, oligodontia was found in a lower percentage in older age groups, due to the fact that, as dogs grow older, their owners, breeders and dog-lovers get less interested in dog shows and less frequently have their dogs examined for dental condition.

Periodontitis, by which we mean any changes involving the top of the root and its alveola, account for almost the same percentage as oligodontia. It can be considered as a serious disease, because it causes dental loss. Its causes are numerous and not fully known (Gad 1986; Hull et al. 1974; Lindhe et al. 1975). However, gingivitis, nutritional secondary hyperparathyroidism (Svanberg et al. 1973), plaque, cremor (Schröder 1965; S axe et al. 1967; Syed et al. 1981), alveolar and pulp infections (Hamp et al. 1984) are the diseases which certainly lead to periodontitis. Rosenberg et al. (1966) report that there are also genetic predispositions for this disease. Our research shows that is the incidence of periodontitis also was significantly different $(p<0.001)$ between dogs of different age groups. The most incidence it was in middle-age group $(75.62 \%)$, while in younger dogs it was not observed. Our results are in line with those of the research carried out by Harvey et al. (1983) who reported that periodontitis occurred in $95 \%$ of dogs above 2 years of age. We have undoubtedly established that periodontitis is more frequent in small breeds, especially in Poodle. The high incidence of periodontitis in small breeds could be explained with their longer life expectancy as compared to large breeds.

Dental fractures were found in 50 cases, which is equal to $19.3 \%$ of all examined dogs. Most of them, i.e. $86 \%$ were the incisor fractures of the upper and lower jaws, which occurred as a consequence of a traffic accident, playing, catching hard objects and hunting. Our observations are in line with those of Harvey et al. (1983) who mentions similar causes.

In our analysis, the incidence of dental fracures was statistically significant different $(p<$ 0.001 ) between dogs of different age groups. There were the most frequent in the middleage group $(56 \%)$ and younger dogs $(40 \%)$, while older dogs account for only $4 \%$.

Dental rotation is most likely a consequence of the selection by which head proportions had been changing in many breeds. Therefore, today many breeds feature a smaller head, shorter jaws and a smaller dental arch. Considering that the genetic shape and size of teeth are easily changeable, in such small jaws dental eruptions are likely to occur at certain angles. The rotated teeth often do not pierce through the alveolar bone but remain impacted. 
Therefore, the rotation is often closely associated with impaction. Supporting this statement is the fact that rotation is most frequent in small breeds ( $\mathrm{Schulze} 1970)$. Our results showed that the incidence of dental rotation differed significantly $(p<0.001)$ between different age groups. The highest incidence was in the youngest age group.

Persisting deciduous teeth and supernumerary teeth do not represent a serious anomaly, both from the medical and cynological points of view, especially if they are extracted on time.

Hennet (1997) says that the exact ethiopathogenesis of persisting deciduous teeth is unknown, although hereditary component plays an important role. Our experience shows that the persistence of deciduous teeth causes malalignment of the permanent teeth which results in maloclusion if they are not extracted in time, which is in line with Harvey et al. (1983) report.

The incidence of tooth rotation, persisting deciduous teeth and supernumerary teeth showed also significant differences $(p<0.001)$ among different age groups with the highest incidence found in youngest dogs.

Finally, we can conclude, considering the hereditary nature of the anomalies such as congenital oligodontia, tooth rotation and retained deciduous teeth, the dog breeders should provide for timely X-ray examination and, in case of these anomalies, exclude the affected dogs from futher breeding.

\section{Nemoci zubů u psů: retrospektivní studie radiologických nálezů}

Cílem předkládané studie bylo zhodnotit počet patologických dentálních změn a anomálií u psů. Incidence dentálních nemocí byla radiologicky vyšetřována u 139 psů a 120 fen, ve věku od sedmi měsíců do 15 let. Mezi vyšetř̌ovanými jedinci bylo 235 psů čistokrevných a 24 kř́iženců. Dutina ústní byla klinicky vyšetřena a zrentgenována. Sledovali jsme incidenci a rozsah oligodoncie, periodontitidy, dentálních fraktur a rotací, perzistujících dočasných zubů včetně zubů nadpočetných. Bylo zjištěno, že více než 30\% psů má více než jednu anomálii. Oligodoncii jsme zaznamenali v 45,17\%, periodontitidu v $44,40 \%$, fraktury v $19,30 \%$, rotaci zubů v $11,59 \%$, perzistující dočasný chrup v $5,40 \%$ a nadpočetné zuby v $3,86 \%$ případech. Naše výsledky prokázaly, že se incidence dentálních změn a anomálií významně lišila u psů různých věkových kategorií. Nejvyšší výskyt oligodoncie, rotace zubů, perzistence dočasných zubů a zubů nadpočetných byl zjištěn u nejmladší věkové skupiny $(p<0,001)$, dentální fraktury u střední věkové skupiny $(p<0,001)$ a periodontitida u psů středního věku a u psů nejstarších $(p<0,001)$. Při výskytu dědičných anomálií, např. vrozené oligodoncie, rotace zubů a perzistentních deciduálních zubů, by měli chovatelé nechat psy zavčas radiologicky vyšetřit a v pozitivním př́ípadě vyřadit $\mathrm{z}$ dalšího chovu.

\section{References}

BOOESSNECK, J. 1955a: Angeborene Oligodontie bei Haustieren und ihren Wildverwandten. Tieraerztl. Umsch. 10: $138-141$

BOOESSNECK, J. 1955b: Angeborene Oligodontie bei Haustieren und ihren Wildverwandten. Tieraerztl. Umsch. 10: $145-168$

BOOESSNECK, J. 1955c: Angeborene oligodontie bei Haustieren und ihren Wildverwandten. Tieraerztl. Umsch. 10: $202-203$

BODINGBAUER, J., HAGER, G 1959a: Zur Frage der Aetiologie der Oligodontie des Hundes. Wien Tieraerztl. Mschr. 46: 213-230

BODINGBAUER, J., HAGER, G. 1959b: Zur Frage der Aetiologie der Oligodontie des Hundes. Wien Tieraerztl. Mschr. 46: 313-321

BODINGBAUER, J. 1960: Retention of teeth in dogs as a sequel to distemper infection. Vet. Rec. 72: 636-638

GAD, T. 1968: Periodontal disease in dogs. I. Clinical investigation. J. Periodont. Res. 3: 268-272

HAMP, S. E., OLSSON, S. E., MADSEN, K. F., VIKLANDS, P., FORNELL, J. 1984: Macroscopic and radiologic

investigation of dental diseases of the dog. Vet. Radiol. 25: 86-92

HARVEY, C. T. 1996: Preliminary data of 1995 National Companion Animal Study. Vet. Dent. 13: 56 
HARVEY, C. E., BRIEN, J. A., ROSSMAN, L. E. et al. 1983: Textbook of veterinary internal medicine. WB Saunders Co., Philadelphia, pp. 1147-1160

HENNET, T. P. 1997: The persistence of deciduous teeth in dogs and cats and its consequences. Pratique Medicale and Chirurgicale de l'Animale de Compagnie. 32: 69-76

HULL, P. S., SOAMES, J. V., DAVIES, R. M. 1974: Periodontal disease in a beagle dog colony. J. Comp. Pathol. 84: $143-150$

LINDHE, J., HAMP, S. E., LOE, H. 1975: Plaque-induced periodontal disease in beagle dogs. A 4-year clinical, roentgenographic and histometrical study. J. Periodont. Res. 10: 243-255

ROSENBERG, H. M.; REHFELD, C. E., EMMERING, T. E. 1966: A method for the epidemiologic assessment of periodontal health-disease state in a Beagle hound colony. J. Periodontol. 37: 208-213

SAS Copyright 1989-1996: SAS Institute Inc., Cary, NC, USA

SAXE, S. R., GREENE, J. C., BOHANNAN, H. M., VERMILLION, J. R. 1967: Oral debris, calculus and periodontal disease in the beagle dog. Periodontics 5: 217-225

SCHULZE, C. 1970: Developmental abnormalities of teeth and jaws. Thoma's oral Pathology. $6^{\text {th }}$ edition. St. Louis, Mosby Company, pp. 1047-1067

SCHROEDER, H. E. 1965: Crystal morphology and gross structures of mineralizing plaque and of calculus. Helv. Odontol. Acta 9: 73-86

SVANBERG, G., LINDHE, J., HUGOSON, A., GRONDAHL, H. G. 1973: Effect of nutritional hyperparathyroidism on experimental periodontitis in the dog. Scand. J. Dent. Res. 81: 155-162

SYED, S .A., SVANBERG, M., SVANBERG, G. 1981: The predominant cultivable dental plaque flora of beagle dogs with periodontitis. J. Clin. Periodontol. 8: 45-56

ZONTINE, W. J. 1975: Canine dental radiology. Radiographic technique, development and anatomy of the teeth. J. Am. Vet. Radiol. 16: 75-83 